\title{
Open-air Museums - the Future of the Presentation of Spiritual and Architectural Heritage
}

\author{
Lucie Rychnová - Patrik Maturkanič - Katarína Slobodová Nováková \\ - Martina Pavlíková
}

\author{
Lucie Rychnová \\ University of Chemistry and Technology in Prague \\ Faculty of Chemical Technology \\ Department of Chemical Technology of Monument Conservation \\ Czech Republic \\ e-mail: Lucie.Rychnova@vscht.cz \\ ORCID: 0000-0003-4936-5177
}

Patrik Maturkanič

Comenius University in Bratislava,

Faculty of Roman Catholic Theology of Cyril and Methodius

Kapitulská 26

81458 Bratislava

Slovakia

e-mail: maturkanic@freth.uniba.sk

ORCID: 0000-0002-1087-3847

Katarína Slobodová Nováková

Department of Ethnology and World Studies,

University of Ss. Cyril and Methodius in Trnava

Námestie J. Herdu 2

91701 Trnava

Slovakia

e-mail:katarina.novakova@ucm.sk

ORCID: 0000-0002-8331-7040

Martina Pavliková

Department of Journalism, Faculty of Arts

Constantine the Philosopher University in Nitra

B. Slančíkovej 1

94974 Nitra

Slovakia

e-mail:mpavlikova@ukf.sk

ORCID: 0000-0002-6738-3320

\section{Open-air Museums - the Future of the Presentation of Spiritual and Architectural Heritage}

The origins of "open-air museums" date back to the nineteenth century and from the very beginning were closely linked to efforts to capture, preserve and present folk culture. However, during the course of the twentieth century, especially in its later part, the concept of open-air museums began to expand. Open-air museums were founded that focused on urban, industrial and military environments, ecological issues, or on charting the life of prehistoric and ancient cultures. Along with this, the methodological concept for this specific type of institution saw some development, and the interdisciplinary approaches expanded in response, covering a wide range of humanities as well as natural sciences. Besides the academic approach, a social and community overlap is also required from these institutions. This article poses the question of how the concept of open-air museums can continue to develop and what direction the role of presenting cultural heritage in an open landscape could take in the future. The arguments 
herein are based on the philosophical and spiritual dimension of man's dwelling in the world and his relationship to the landscape in which he lives. We believe that the future of open-air museums should, wherever possible, focus on the preservation of monuments in their historical context and especially in their natural links in terms of landscape, urbanism and architecture. To ensure this concept remains sustainable, it is necessary that these monuments be involved in the life of villages and communities, ideally also on the basis of cooperation between academia and local entities, which are usually villages or municipalities and citizens' initiatives. Examples of such a direction can be seen in the founding and running of Rochus Park in the Uherské Hradiště region and in the concept of the association of villages called Mariánská zahrada in the Jičín region, both in the Czech Republic.

Keywords: open-air museums; vernacular architecture; countryside; landscape; national heritage; Czech and Slovak Republic

\section{Introduction}

The English notion of the open-air museum (Freilichtmuseum in German, muzeum v prírodé in Czech, where it is often also referred to as skanzen) denotes, according to a definition by one of the leading figures in this branch of museum work and also the first Czechoslovak theoretician, Jiří Langer, "an academic institution which, on a scientific basis, interprets and preserves folk culture in the form of a specialised museum exhibition in the open air". ${ }^{1}$ It should incorporate interconnections of space, time, society, culture and nature and present a comprehensive picture of folk culture. However, since the time when the concept of "open-air museums" was first approached in methodological terms in the 1980s, based on Langer's aforementioned article, the thematic scope of "museums in nature" has considerably expanded. ${ }^{2}$ Today, openair museums offer, besides an effort to capture the tangible as well as intangible manifestations of rural folk culture, also some urban, industrial or military phenomena, ${ }^{3}$ or efforts to reconstruct the life of prehistoric and ancient cultures. ${ }^{4}$ This is the direction in which the methodological concept of "open-air museums" should necessarily develop, and also expand to include the interdisciplinary approaches we hear so much of today, in which a broad range of the humanities as well as the natural sciences are addressed. Besides the scientific aspect, the concept should, however, unavoidably carry societal content. How can the concept of open-air museums continue to develop? In what way should the role of presenting cultural heritage in an open landscape develop in the future? The first part of this article will provide a brief overview of the history of this specific means of presenting cultural heritage, and we will look at some contemporary examples, and will also outline the philosophical bases from which the possible directions and future scopes can stem, and eventually the article will present

\footnotetext{
${ }^{1}$ LANGER, Jiř́i. Muzeum v prrírodě jako forma tezaurace památek lidového stavitelství [The Open-air Museum as a Form of Embalming Vernacular Architectural Heritage]. Národopisné aktuality. vol. 13, no. 3, 1976, pp. 179-184; Idem. Národopisná muzea v prírodě. Teoretická a metodická východiska ke realizaci [Ethnographical Museums in Nature: Theoretical and Methodological Bases for Their Realisation]. Rožnov pod Radhoštěm: Valašské muzeum v přírodě, 1981.

${ }^{2}$ LANGER, Jiří. Atlas památek. Evropská muz̨ea v prírodě [Atlas of Monuments. European Open-air Museums]. Praha: Baset, 2005.

${ }^{3}$ Such as the Industrial open-air museum of New Lanark, the Chabówka Rolling-Stock Heritage Park "Skansen" in Poland showing railway history, Den Gamble By in Denmark showing urban life, etc.

${ }^{4}$ The first example in Slovakia is the Archeoskanzen Havránok, built in the site of a Celtic settlement dating back to the Late Iron Age above the River Vah valley. One site worth mentioning in the Czech Republic is the Archeoskanzen Modrá near Uherské Hradiště, Moravia. Among Central European open-air museums, life in a Roman camp is very well presented by Museum Camuntinum in Lower Austria.
} 
an example demonstrating how specific museum activity could be carried out not only in the open and in situ, but also within the framework of man's modern social structures.

\section{A View into the Past and an Outlook to the Future?}

The history of open-air exhibitions with purpose-made collections in folk culture goes back to the nineteenth century. The first ever exhibition of rural buildings is thought to be the collections of King Oscar II (Kong Oscar IIs Samling), opened to the public at the summer royal residence in Bygdøy, a district of Oslo, in 1882. Its concept, amongst other things, also carried a broader ideological message: it contained five original wooden buildings of rural architecture that were transferred from various parts of Norway to the royal court, through which the exhibition was intended to symbolise the bond between the ruler and the people. ${ }^{5}$ The Norwegian collection of folk buildings inspired the Swedish teacher and folklorist Artur Immanuel Hazelius (1833-1901), the founder of the Swedish Scandinavian Ethnographical Collection (Skandinavisk-etnografiska samlingen), who opened an open-air exhibition of complete collections of folk architecture in 1891, presenting what was then an unprecedentedly large variety of folk culture, costumes, traditional crafts and animal breeding, which was located in Stockholm on Djurgården island, at a site locally known as Skansen. It gained worldwide popularity, and in some countries this local name has become synonymous with an open-air exhibition. ${ }^{6}$

The oldest Czech ethnographical museum was founded by the Archduke Ludwig Salvator of Austria in Přerov nad Labem around the year 1900. However, the most well-known and largest open-air museum in the Czech Lands is the Wallachian Open Air Museum (Valašské muzeum v prýrodě) in Rožnov pod Radhoštěm, founded by the brothers Alois and Bohumír Jaroňka in 1925. It was Alois who drew inspiration directly from the Nordic countries - he had visited Skansen in Sweden on his travels, as well as the renowned Nordic open-air museum in Aarhus, Denmark. ${ }^{7}$

Since then, many other open-air museums (hundreds but, depending on the estimates and parameters included, it could be thousands) were established throughout the world during the twentieth century. This includes dozens of such institutions in the Czech Republic and in the Slovak Republic. ${ }^{8}$

What are the key attributes that these exhibitions should have? The aforementioned Czech theoretician and museum scientist Jiř́ Langer defines the following four attributes of these institutions: They should include historical buildings that were firmly linked with life in the rural areas or within a defined territory. They should also present the authentic environment in which these buildings were located: fields, gardens, orchards, vineyards, forests, etc. The third, wherever possible, is an indication of the urban planning relationships, which means the

\footnotetext{
${ }^{5}$ In 1970 the collection was acquired by the Norway Folk Museum (Norsk Folkemuseum). For more, see FREDRIKSEN, Anders - MØRCH, Monica. King Oscar II's collection of authentic medieval houses at Bygdøy, Oslo. In: Bulletin för trädgårdshistorisk forskning, vol. 30, 2017, pp. 13-15.

${ }^{6}$ See e.g. the chapter on this achievement in ALEXANDER, EDwArD P.. Museum Masters: Their Museums and Their Influence, Walnut Creek - London - New Delhi: Altamira Press, 1995.

${ }^{7}$ The Aarhus Museum was opened to the public in 1914 as the Old Town House. Now the Den Gamle By (Old Town) covers municipal houses dating back to the sixteenth-nineteenth centuries from various parts of Denmark. On its history and the present concept, see BLOCH RAVN, Thomas. Den Gamle By: AWindow into the Past. Aarhus: Gyldendal, 2002.

${ }^{8}$ For an overview of these, see DVOŘÁČEK, Petr. Skanzeny Ceské a Slovenské republiky [Open-air Museums in the Czech and Slovak Republic]. Praha: Academia, 2010.
} 
location of the building within the settlement unit (in the village or municipality, or in relation to other buildings). And the fourth attribute is that the interiors of these buildings should also be presented, thus implying how the inhabitants there lived.'

There are two major concepts behind open-air museums now. The first is based on a conservationist approach, which particularly emphasises the preservation and presentation of the monuments in their original context. These are museums established at the site of the original settlement. The second concept is based on museum science, where the buildings are extracted from their original context and introduced (reconstructed) in a new place, although that site should reflect the original context of the buildings as much as possible. Both of these two present concepts have their advantages as well as disadvantages. The disadvantages of the "conservationist" approach are its seasonal nature and the desolation of the originally inhabited sites, while having buildings transferred to an environment other than their original one may make them seen less authentic. ${ }^{10}$

In recent times, as mentioned in the introduction, the question has arisen as to how the concept of this kind of museum activity could be innovated in the twenty-first century. How to make it even more accessible for the people of today? The debate has been quite lively in this respect since the 1990s. ${ }^{11}$ There has been a recurrent call for greater inclusion of contemporary historiography's view of history: The underlining of gender topics, race and nationality issues, the reflection of one's history from the perspective of twentieth-century dictatorships, an emphasis on ecology, or the greater involvement of civil society and local initiatives. ${ }^{12}$ Proposals appear which at the first glance may seem ridiculous, yet in essence are a call for the wider inclusion of the entire dimension of human existence, such as emphasis on the possibility of

\footnotetext{
${ }^{9}$ See LANGER, Jiří. Atlas památek. Evropská muz̨ea v prírodě..., p. 7-12.

${ }^{10}$ See e.g. STACHOVÁ, Alena. Vznik muzeí v př́rodě [The Founding of Open-Air Museums]. In: Prameny a studie, vol. 55,2015 , p. 191.

${ }^{11}$ For an attempt to answer these questions, see e.g. RENTZHOG, Stan. Open Air Museums: The History and Future of a Visionary Idea. Stockholm: Carlssons, 2007, which also includes references to other relevant literature. STEPANYAN, Knarik. Open-Air Museums: Scenario Planning for the Future. In: Advanced Materials Research, vol. 1020, no. 10(2014), pp. 711-715. The latest overview for Eastern Europe is given in BUKOWIECKI, Lukasz. Czas przeszly zatrzymany. Kulturowa historia skansenów w Szwecji i w Polsce, Warszawa: Campidoglio, 2015; and ZUSKINOVÁ, Iveta KOLLÁR, Daniel - ONDREJKA, Kliment -AUGUSTINI, Peter et al. Open-air museums. Bratislava: Dajama, 2008. For the Czech environment, there is a remarkable contribution by KUMINKOVÁ, Eva. Muzéa v prírodé: jedinéná cesta muzejnictví [Open-Air Museums: The Unique Way of Museum Science]. 1. vydání. Rožnov pod Radhoštěm: Národní muzeum v pŕírodě, 2019; For more, see CARSTEN, Jan - FROST, Katarina (eds). Creating Museums: 50 Years Association of European Open-Air Museums = Museen erschaffen : 50 Jabre Verband Europäscher Freilichtmuseeen. Münster - New York: Waxmann, 2016; KOTVASOVÁ, Helena. Múzeá v prírode: koncepcia, realita a vízie : zborník príspevkov zprvébo ročníka konferencie Únie múzei v prírode konanej 15. a 16. mája 2019 v Skanžene Vychylovka. Čadca: Kysucké múzeum v Čadci, 2019; GAWEL, Artur (ed.). Open air museums in Poland. Białystok: Association of Polish Open-Air Museums 2019.

${ }^{12}$ What is important here is also the educational aspect, as reflected e.g. in CHODŹKO, Małgorzata. Muzeum i skansen w kształceniu i wychowaniu : edukacja humanistyczna i cywilizacja techniczna w kontekście pedagogicznym = Museums and open-air museums in education and upbringing: humanistic education and technical civilisations in the context of pedagogy. In: GRACA, Tadeusz - LAŻEWSKA, Dorota (ed.). Edukacja bumanistyczna w kontekście technicyzacii w XXI wieku : w poszukiwaniu pedagogicznej równowagi, Józefów : Wydawnictwo Wyższej Szkoły Gospodarki Euroregionalnej im. Alcide De Gasperi, 2017, pp. 171-188; KLEIN-WROŃSKA, Sonia - KROH, Magdalena SADKOWSKI, Tadeusz (eds). Interaktywna edukacja w muzeach na wolnym powietrzu. Toruń: Stowarzyszenie Muzeów na Wolnym Powietrzu w Polsce, 2016; BRYCH, Mariia. General approaches to spatial formation of open-air museums exhibition. Przestrzeń i Forma: kwartalnik naukowo-dydaktyczny, no. 43 (2020), pp. 113-122.
} 
gastronomic experience as part of these exhibitions. ${ }^{13}$ Some inquiries have gone so far as to ask even provocative questions in some cases, for instance, "Would we invent ethnographicallyfocused museums today?"14

We believe that the principal role as one of the ways to the twenty-first-century concept of open-air museums should be played by the context of buildings, meaning the cultural landscape, and hence also man's relationship to the place in which he lives, i.e., to underline man's existential dimension in the world. After all, the cultural landscape and its historical impact (historical buildings and art monuments) is one of the most endangered components of heritage. The preservation of the cultural landscape is then linked to questions relating not only to conservation, but also to ecology and of sustainability. ${ }^{15}$ At the same time, we are facing, not only in the Czech and Slovak Republic but in Europe generally, the issue of alienation, or the loss of relationship, to the place in which one lives. Well incorporated museum activities in cooperation with local initiatives or directly with the local authorities could help man, or the inhabitants of a certain place, to rediscover their deeper link to the place they live in, not only through getting to know it better (the reconstruction and presentation of historical monuments and art works in the landscape), but also by live remembrance of their past, for instance, by reviving folk and religious feasts. ${ }^{16}$

What arguments can we employ for this approach? For man, the landscape, as outlined above, is fundamentally existential by nature. As such, it is the evidence of the development of human society and culture, it is the imprint of the social roles, and cultural, religious and existential values of its inhabitants, past or present. ${ }^{17}$ Owing to that, it is also a cultural construct of its kind. Landscape, both the real one and the imaginary one which reflects our ideas, is a

\footnotetext{
${ }^{13}$ PAWLIKOWSKA-PIECHOTKA, Anna - ŁUKASIK, Natalia - OSTROWSKA-TRYZNO, Anna - SAWICKA, Karolina. The Rural Open Air Museums: Visitors, Community and Place. In: European Countryside, vol. 7, no. 4, 2015, pp. 195-214. In this sense are also interesting aspects that focus on traditional agricultural features, for more, see e.g.: GWARDZIŃSKA, Żaneta. Agricultural Activity Run By Open-Air Museums in Poland. Muzealnictwo, vol. 62, no. 6, 2021, pp. 115-127.

${ }^{14}$ JACKOWSKI, Aleksander. Czy wymyślilibyśmy dzisiaj muzea etnograficzne? In: Ślaskie Práce Etnografiçne, vol. 2, 1993, p. 27. See also BUKOWIECKI, Lukasz. What Is Missing And Who Misses It?: The Hidden Heritage Of Modernity At Open-Air Museums In Sweden And Poland. In: Politeja, vol. 15, no. 1 (52), pp. 7-24.

${ }^{15}$ MICHALIČKA, Václav. Využití a smysl „experimentální“ a „aplikované“ etnografie [The Use and Importance of "Experimental” and "Applied” Ethnography]. In: Národopisný věstník, vol. 26, no. 1(68), pp. 39-43; ŠUBOVÁ, Dana. Medżinárodná konferencia prírodovedných pracovníkov múzei a pracovnikov múzeí v prírode: z̧borník referátov : Liptovský Mikulás, 2009. Liptovský Mikuláš: Slovenské múzeum ochrany prírody a jaskyniarstva, 2009.

${ }^{16}$ In some present theoretical considerations of the importance of open-air museums, the notion of "genius loci" appears which these museums should help to preserve and remember. See e.g. SEVAN, Olga. Open Air Museums As Ways Of Preserving And Transmitting The Spirit Of Place. In: Proceedings of the 16th ICOMOS General Assembly and International Symposium: "Finding the Spirit of Place - Between the Tangible and the Intangible", Quebec, QC, Canada, 29 September-4 October 2008; BAUMEIER, Stefan. Konservierte Wirklichkeiten : Erhaltungs- und Aufbaustrategien in europäischen Freilichtmuseen [Preserved realities]. Detmold: Westfälisches Freilichtmuseum Detmold, 1995; VOLMER, Lutz (ed.). Musealisierte Häuser: Bausubstan₹, Ideologien, Gründungspersönlichkeiten : ausgewählte Referate der 28. Jahrestagung des Arbeitskreises für ländliche Hausforschung in Nordwestdeutschland und der Interessengemeinschaft Bauernhaus e.V., 18. bis 20. März 2016 in Bielefeld. Münster: Waxmann, 2018.

17 "Landscape is never simply a natural space, a feature of the natural environment. Every landscape is the place where we establish our own human organization of space and time." JACKSON, John B.. Discovering the Vernacular Landscape. New Haven, 1984, p. 156.
} 
collection of myths, memory and history, both real and ideal, produced by our imagination. ${ }^{18}$ We, people, are then part of the environment in which we dwell. Martin Heidegger describes man as an inhabitant of the world. The world spreads between the earth and the sky, and is filled with nature which forms the identity of every living space. Nature determines the principal conditions for the dwelling of man, who then works with these conditions, builds settlements, connects them with ways and, to put it simply, makes nature into the cultural landscape.

Man lives in the landscape. What does this mean from an existential perspective? Christian Norberg-Schulz says that to live means to be oriented in the environment, to identify oneself with it and experience it as meaningful. In finding existential support and uncovering the importance of places, i.e., in his living there in the true sense, man is helped by symbols: architecture and small monuments, both sacral and profane, namely rural buildings, churches, chapels, wayside shrines, crucifixes and wells; by ways; but also for instance by prominent natural phenomena, such as a mountain or a tree monument. Living in the existential sense is therefore the realisation of one's meaningful relationship to a specific place. ${ }^{19}$ Human existence is based on relationships. We define ourselves on the grounds of the relationships we create, not only to others ("I" - "you") but also to our environment ("I come from South Bohemia"). From a psychological perspective, it is a well-known fact that man feels good in a landscape that reminds him of the landscape with which he established a relationship in his childhood, the landscape of bome. ${ }^{20}$

The spiritual dimension of human existence is also developing in the landscape of home. The landscape is understood as a network of meanings bound to transcendental contents - the architecture structures the landscape and refers to the sacral overlap. This concept could be hard to imagine for today's secularised society, or even almost abstract in a certain perspective. Here we can refer to Max Weber's often reflected concept of the "uncharming of the world" (Entzauberung der Welt), ${ }^{21}$ which is still considered today within the context of secularisation ${ }^{22}$ and from our viewpoint of our (in)ability to read and decode religious meanings. For our forefathers, however, and therefore also in the cultural landscape of the past, space and time were sacred ("encharmed"). And it is in that very understanding, and decoding, of the sacral and transcendental contents in the landscape, i.e. in the space of human existence, where openair museums could play an important role.

\footnotetext{
${ }^{18}$ SCHAMA, Simon. Landscape and Memory, New York: Knopf, 1995; COSGROVE, Denis - DanieLs, Stephen. The Iconography of landscape. Essays on the symbolic representation, design and use of past environments. Cambridge: Cambridge University Press, 1988; DUNCAN, James S. - LEY, David. Place/culture/representation. London-New York: Routledge, 1993; for a summary of the latest approaches and trends, see DELUE, Rachel - ELKINS, James. Landscape Theory. New York, 2008.

${ }^{19}$ And in this form, it is also the fulfilment of one of man's existential needs; see NORBERG-SCHULZ, Christian. Genius loci: Towards a Phenomenology of Architecture. New York: Rizzoli, 1979, pp. 5-23.

${ }^{20} \mathrm{It}$ is not without reason that the notion the landscape of home becomes the motto for many events and publications in which the landscape is concerned.

${ }^{21}$ WEBER, Max. Sociologie náboženství [Sociology of Religion]. Praha: Vyšehrad, 1998; SCHLUCHTER, Wolfgang. Die Entrauberung der Welt, Túbingen: Mohr Siebeck, 2009.

${ }^{22}$ Havelka, Miloš. „Odkouzleni““ versus sekularizace?! [“Uncharming” vs Secularisation?! In: Sociológia 44, 2012, Issue 5, pp. 564-578.
} 


\section{An Example from Recent Past and the Search for the Ideal Space? Rochus Park and Mariánská zahrada}

One example of a recently established open-air museum which is also a response to calls from local initiatives and has closely cooperated with the local authorities is Rochus Park, a cultural and historical complex established in Uherské Hradiště, Moravia around 2012. It also includes the newest ethnographical museum in the Czech Republic. The "Park Rochus" publicbenefit corporation, founded by the municipality of Uherské Hradiště in 2010, contributed to the creation of the complex. ${ }^{23}$ Its core intention was the revitalisation of a former military training ground. The idea of creating a complex allowing ethnographical presentation in the premises then used by the army was considered as early as in the 1960s. However, these efforts failed because of the military purposes for which the area was used. In the 1970s another plan was raised to build a conservation area that would include, amongst other things, the collection of vineyard structures in the Soví hora quarter and some other selected buildings from the Uherské Hradiště district that were to have been transferred here. This plan was never accomplished, either. ${ }^{24}$ Discussions over the use of the former military exercise field were renewed after the year 2000 when the army had abandoned it. The municipal council declared its support for the idea of establishing a space for not only educational but also recreational purposes - the founding of a park with an ethnographical exhibition.

In 2005, the area was declared a NATURA 2000 Site of European Importance following the discovery of the domestic silk moth. In the light of this fact, a concept landscape study was prepared, ${ }^{25}$ and in 2009 an academic study entitled "The Rochus Open Air Museum”, prepared by the Slovácké Museum in Uherské Hradiště, was presented. ${ }^{26}$ The Park Rochus association was founded in the following year and became the administrator organisation, acquiring all the organisational and administrative work from the municipality. The first building was transferred to the park in 2012, and the Rochus Open Air Museum was inaugurated in 2016. The "Park Rochus" natural, cultural and historical complex and the adjacent vineyards offer a hiking trail with viewing points, places for a stroll, family trips and guided tours. It has a view of the Central Moravian Carpathian Mountains, and the perception and presentation of the landscape is a substantial element of the complex. There are also some historical buildings, namely the Pilgrimage Chapel of St Roch in the centre of the complex, burgher wine cellars in Vinohradská St dating back to the eighteenth and nineteenth centuries, and other rural buildings. In this context, the chapel of St Roch is an important element of the local history just like many chapels, churches and also statues dedicated to this patron, it is a remembrance of the plague epidemic which affected Uherské Hradiště in 1680. Symbolically, the chapel

\footnotetext{
${ }^{23}$ The company SYNOT REAL ESTATE was originally involved in the founding of the association, while the municipality of Uherské Hradiště is now the sole founder.

${ }^{24}$ For details on the development of this idea to establish an open-air museum, see BLAHŮŠEK, Jan. Jak se staví (skan)sen. Vznik Uherskohradišt'ského muzea v Př́rodě v historických souvislostech [How a Skansen Is Built: The Founding of Uherské Hradiště Open-air Museum in Historical Contexts]. In: Slovácko: společenskovědní recenzovaný časopis pro moravsko-slovenské pomezí / Uherské Hradiště: Slovácké muzeum v Uherském Hradišti, 2016, pp. 332-346. See also KUMINKOVÁ, Eva. Muz̨ea v prírodé: jedinečná cesta muzejnictví [Open-air Museums: The Unique Way of Museum Science]. 1. vydání. Rožnov pod Radhoštěm: Národní muzeum v př́rodě, 2019, pp. 197-207.

${ }^{25}$ The study was conducted by Prof. Ivar Otruba of the Mendel University in Brno.

${ }^{26}$ The external examination was provided by the ethnographer and former director of the renowned Wallachian Open Air Museum in Rožnov pod Radhoštěm, Jaroslav Štika. The comprehensive use proposal is available at https://www.mesto-uh.cz/informace-o-parku-rochus (online, accessed on 25 September 2021].
} 
is the spiritual centre of this complex. ${ }^{27}$ Folk-style events are held here associated with the liturgical and economic year: the Slavic carnival, a show of traditional Easter customs, erecting the maypole, opening up the pastures, a fair, Advent and Christmas traditions. The complex includes orchards of old fruit varieties typical of the region.

What makes this concept new and unique, and how does it offer a perspective and the possibility of running ethnographical collections in the open air? The founding of the complex, as mentioned above, was not only the work of academia, as is typical for this type of institution in the Czech Republic and Slovakia, but an important role was played by the municipality, a public-benefit corporation, and also representatives of the business sector. This combination of interest groups and local associations came about as emphasis was put not only on the academic aspects, but also on marketing support and the leisure side of the life of the local people. The aim of this combination was to ensure the economic sustainability of the project (e.g. its use for tourism) while also strengthening the civil aspect in the life of the museum, park and the landscape itself. It is obvious that such an intention may have certain shortcomings, especially the constant effort to balance the views and approaches of all the interest groups involved. It should be mentioned that the initiative to found and build Rochus Park also included the fact that the municipality pro-actively clarified and explained the reasons behind the intention to build the park, and it is apparent that it was not met with understanding by everyone. ${ }^{28}$

The second example to be mentioned here is not exactly an open-air museum, but a successful initiative where efforts to maintain the historical impact in the cultural countryside landscape combine with an accent on historical buildings and art monuments in forms which are attractive for tourism and also remind the locals of the historical heritage in the original landscape context. Here the sacral, rural and farming architecture gradually became an inseparable part of the "landscape of home" for the locals, or in other words, it is integrated into their living space as a matter of course. This "project" is carried out in the former manors of the House of Schlik (Šlik) in the region near the town of Jičín and covers a relatively large area where especially two members of the House of Schlik carried out a series of landscape and urban planning undertakings at the end of the seventeenth century and in the eighteenth century, thus giving rise to a unique "Baroque landscape composition". This composition is still partially apparent in the region; the various roads, pathways and building monuments it comprises are still perceived in the life of the locals, and awareness of them has been kept alive owing to the cooperation of the municipalities, villages, academicians, NGO's and individual enthusiasts.

This (cultural) landscape composition emerged in an area covering the former manors of the House of Schlik, namely Veliš, Vokšice, Staré Hrady, Kopidlno and Jičíněves. It comprises mostly cultural landscape with fields, forests, original orchards and built-up areas in the

${ }^{27}$ For more, see BEZDĚČKA, Pavel - RAŠTICOVÁ, Blanka. Mařatice - Rochus výżnamná přrodní lokalita Evropy. Uherské Hradiště: Město Uherské Hradiště, 2009, p. 12.

${ }^{28}$ The fact that the creation of the park did not always meet with a positive response can be seen, for instance, in an interview posted on the park's website, where the mayor replies to the question "What, in your opinion, should every citizen of the town know about Rochus?" as follows: "Disregarding the importance of the place as such and the meaning of preserving the area for future generations, people should be aware that the municipality is not robbing them when it provides funding for Rochus projects, and that they are not deprived of any money for other things. Some ask why we don't put the money into pavements, road repairs, cleaning the town, or services. It is simply because we can't: the money for Rochus is almost entirely obtained from subsidies that have a defined purpose, which is this project." See https://www.mesto-uh.cz/park-rochus (online, accessed on 25 September 2021). 
countryside. There are only two larger urban settlements in the whole territory, the small towns of Kopidlno and Libáň, while Jičín as the district capital was in the neighbouring manor of the House of Trauttmansdorff and served as the only larger urbanistic setting for the local landscape. Frantz Joseph Schlik (František Josef Šlik, 1656-1740) and his wife and later widow Anna Josepha née Krakowska of Kolowrat (Anna Josefa Krakovská z Kolovrat, 1691-1771) especially take the credit for the specific shaping and formation of this rural landscape. Step by step, in the form of small or bigger building undertakings and also through a pro-active approach to the management of their land, they had many buildings erected or redesigned, and built new roads, or laid out observation lines, to connect them. The lifelong efforts of this couple resulted in what was not exactly a collection of individual structures but rather a unified array of architectural and spiritual relationships that shape a landscape composition. To name but a few of these buildings, for instance, the churches of St James the Greater in Kopidlno, Sts Simone and Jude in Chyjice, the Exaltation of the Holy Cross in Ostružno, and St Franciscus of Assissi in Staré Místo were either built or redesigned; the chapels of Loretto, St Anne, the Holy Trinity and the Guardian Angel, the Holy Sepulchre in Drahoraz, the churches of St Wenceslaus in Veliš and the Ascension in Slatiny were newly built, as were the granaries in Vokšice and Střevač. All of these places and buildings, both profane and sacral, played a significant role in the functioning of the manor.

The Loretto chapel, built near the highest point of the area, the hill Veliš, was the centre, as it were, of this landscape composition, towards which the landscape lines ran from other places in the former manors. The chapel itself took advantage of its dominant position on the Velišský ridge, and anticipating the excellent view of the surrounding countryside, it was not composed merely as a chapel, but its flat roof also served as an observation point and also the focal point of other parts of this landscape composition. There were fours ways in different directions, laid out approximately on a cross plan, formed in the terrain as forest cuts that met at the site of the chapel. The northern one connected it directly with the village of Ostružno and the chapel of St Anne on the hill of the same name. The eastern way was pointed at the Chapel of Guardian Angel and ran further to the farm in Vokšice, dominated by an extensive granary and a little chateau. The southern axis was aimed at the palace in Jičiněves and the adjacent grand farmstead. This scenery was complemented by the traditional rural settlements of Podhradí and Hlásná Lhota, much of which has still been preserved. ${ }^{29}$ The principle of landscape formation of this kind was not to build a single large settlement centre that would command the whole space, but the exact opposite: to provide every site with its own landmark, and to interlink these landmarks by relationships in the landscape.

This idea of the House of Schlik was taken up by the association of municipalities called Mariánská zahrada (Svazek obcí Mariánská zahrada, meaning The Garden of the Virgin Mary in Czech), made up of villages in the former manors. The central idea of this initiative, which was founded in 2004, is to strengthen the local people's relationship to the place in which they live, raise awareness of their own roots, re-establish respect for their environment, and promote a pro-active approach to life. At present, the key topics are the use of the historical spiritual and physical potential for the social and economic development of the villages, and the preservation of the Baroque landscape composition as a means of communicating the

\footnotetext{
${ }^{29}$ On the landscape composition and ideological concept of the Baroque landscape, see RYCHNOVÁ, Lucie. František Josef Šlik a česká barokní krajina. Život šlechtice na východočeském venkově [František Josef Šlik and the Czech Baroque Landscape: The Life of an Aristocrat in the East Bohemian Countryside]. Praha 2020.
} 
space between settlements and landscape in the sense of the mutual adaptation of natural, agricultural, structural and transport components. The relicts of the past cultural landscape are automatically considered in the strategic development plans of the villages. In cooperation with experts from the local museum (RMaG Jičín), the district archive, universities and national heritage conservationists, a series of academic studies have been conducted which designate places that bear some meaning in the local landscape, interpret them and present them to the locals as well as visitors. ${ }^{30}$

The aforementioned landscape composition with these historical relics can be explored today with the help of special maps and schedules prepared as part of the activities of this association. Information boards have been installed at important points in the landscape and provide the necessary explanations and descriptions. ${ }^{31}$ Events are held on a regular basis to commemorate the importance of the buildings and specific places, such as masses, processions, concerts, meetings at important sites, for instance at the renewed conciliation cross near Veliš. As the landscape here also includes examples of rural architecture or period farm buildings, it would also be good to consider their future use as part of the presentation of the cultural heritage by means of interior installations that could be prepared in cooperation with museum scientists. In general, however, the focused effort of these villages to maintain, reconstruct and accentuate building monuments and their relationships in the landscape creates a highly specific and, for the locals, also a natural concept of presentation of the cultural and landscape heritage, and shares some attributes which are typical for open-air museums. ${ }^{32}$

\footnotetext{
${ }^{30}$ HENDRYCH, Jan - LÍČENÍKOVÁ, Michaela. Historická krajina Jičínska [Historical Landscape of the Jičín Region]. In: Zprávy památkové péce. Časopis státni památteové péče 3, 1998, pp. 76-83; HÁJEK, Pavel. Česká krajina a baroko. Urbanismus českého baroka na př́kladu města Jičína a okolí [Czech Landscape and the Baroque: The Urban Planning of Czech Baroque Taking the Town of Jičín and Its Environs as an Example], Praha: Malá Skála, 2003. ŠEJN, Miloš, Nékolike poznámek ke krajině [Several Remarks on Landscape]. In: Schlikové na Jičínsku, katalog k výstavě v Okresním muzeu a galerii v Jičíně, Jičín, 1999, p. 8; GotTLIEB, Jaromír. Zahrada mariánská [Garden of the Virgin Mary]. In: Tvár naši zemé - krajina domova 3. Duchovní rozměr krajiny, Lomnice nad Popelkou 2001, pp. 31-45.; HERMOVÁ, Hana - POLKOVÁ, Miroslava - WATZKO, Karel. Analýza vývoje území jako podklad pro současné plánování (na príkladu Mariánské zahrady na Jičínsku) [Analysis of Development of an Area as Underlying Document for the Present Urban Planning (Taking the Marianska Zahrada Area in the Jičín Region as an Example]. In: Historická geografie, No. 34, 2007, pp. 350-371; STRÁNÍKOVÁ, Jana - ŘíHOVÁ, Vladislava. Kostel sv. Václava ve Veliši. Výstavba, vybavováni a okolnosti vzniku (1747-1752) [The Church of St Wenceslas in Veliš. Construction, Furnishing and Circumstances of Founding (1747-1752)]. Pardubice 2014; RYCHNOVÁ, Lucie. Stavebník František Josef Šlik [Frantz Joseph Schlik the Builder]. In: Východočeský sbornik historický, no. 21, 2012, pp. 163-196; RYCHNOVÁ, Lucie. Spisy o architektuře, umění, zahradách a „dobrém životě“ v knihovně Františka Josefa Šlika [Publications on Architecture, Art, Gardens and the "Good Life" in the Library of Frantz Joseph Schlik]. In: Marginalia Historica, vo. 5, no. 2, 2014, pp. 107-142; RYCHNOVÁ, Lucie. František Josef Šlik a česká barokni krajina: život šlechtice na východočeském venkové. Praha: Scriptorium, 2020 and others.

${ }^{31}$ An overview of the activities of the Marianska zahrada association was published, for instance, in a brochure entitled Mariánská zahrada v našem čase [Mariánská zahrada in Our Time], Jičín 2014. The texts were written by the former director of the Jičín Museum Jaromír Gottlieb, an archivist in the Jičín District Archive Eva Bílková, and the chairman of the association Eliška Formanová. This is also a good example of successful cooperation between local experts and village representatives.

32 The importance of open-air museums for the conservation and preservation of rural architecture has been recently discussed, see: PEDRAM, Behnam - EMAMI, Mohammad Amin - KHAKBAN, Mozhgan. Role of the Open-Air Museum in the Conservation of the Rural Architectural Heritage. In: Conservation Science in Cultural Heritage, vol. 18(2018), no. 12, pp. 101-120.
} 


\section{Conclusion}

We believe that the idea of an open-air museum should develop in the future in the sense of the existential dimension of man's "living" in the world and especially in the landscape he calls home. Only in the environment one calls home and to which one has a relationship, can the idea of an open-air museum become a real living idea, as it can be at all times naturally revived by the locals. They find, through the building monuments and a well-kempt cultural landscape which follows up on the historical shape of that landscape, the very meaning of their "dwelling in the world" in the phenomenological sense. If the buildings and protected landscape elements become part of the ordinary life of the locals in a specific place, they will be naturally living ones, and for these locals they will also "bear meaning". This would facilitate the revival of the folk tradition as well as religious rites, as those will not be just part of an "exhibition", but will really exist "in situ". It is therefore quite desirable for museum-type institutions and their experts to cooperate with villages and municipalities as well as local civil initiatives. In this respect, "living open-air museums" can be created.

\section{References}

ALEXANDER, Edward P. (1995). Museum Masters: Their Museums and Their Influence. Walnut Creek - London - New Delhi: Altamira Press, 1995. ISBN: 0-7619-9131-X.

BAUMEIER, Stefan (ed.) (1995). Konservierte Wirklichkeiten: Erhaltungs- und Aufbaustrategien in europäischen Freilichtmuseen [Konservierungvon Holzbauten, Kopien historischer Gebäude in Freilichtmuseen; Bericht über die zweite Tagung der Arbeitsgruppe des Verbandes Europäischer Freilichtmuseen in Detmold vom 23. - 25. September 1994] = Preserved realities. Detmold: Westfälisches Freilichtmuseum Detmold. ISBN: 3-926260-24-1.

BEZDĚČKA, Pavel - RAŠTICOVÁ, Blanka (2009). Maratice - Rochus významná prírodní lokalita Evropy. Uherské Hradiště: Město Uherské Hradiště. ISBN 978-80-904380-2-6.

BLAHŮŠEK, Jan (2016). Jak se staví (skan)sen. Vznik Uherskohradišt'ského muzea v Př́rodě v historických souvislostech [How a Skansen Is Built: The Founding of Uherské Hradiště Open-air Museum in Historical Contexts]. In: Slovácko: společenskovědní recenzovaný časopis pro moravsko-slovenské pomezí / Uherské Hradiště: Slovácké muzeum v Uherském Hradišti, no. 58, 2016, pp. 332-346.

BLOCH RAVN, Thomas (2002). Den Gamle By: A Window into the Past. Aarhus: Gyldendal. ISBN: 978-8702015713.

BRYCH, Mariia (2020). General approaches to spatial formation of open-air museums exhibition. In: Przestrzeń i Forma: kwartalnik naukowo-dydaktyczny, no. 43, pp. 113-122.

BUKOWIECKI, Lukasz (2015). Czas przeszly zatraymany. Kulturowa historia skansenów w S zwecji $i$ w Polsce. Warszawa: Campidoglio. ISBN: 978-83-927476-4-2

BUKOWIECKI, Lukasz (2018). What Is Missing And Who Misses It?: The Hidden Heritage Of Modernity At Open-Air Museums In Sweden And Poland. In: Politeja, vol. 15, no. 1 (52), 2018, pp. 7-24.

CARSTEN, Jan - FROST, Katarina (eds) (2016). Creating Museums: 50 Years Association of European Open-Air Museums = Museen erschaffen : 50 Jahre Verband Europäischer Freilichtmuseeen . Münster - New York: Waxmann. ISBN: 978-3-8309-3420-2. 
COSGROVE, Denis - Daniels, Stephen (1988). The Iconography of landscape. Essays on the symbolic representation, design and use of past environments. Cambridge: Cambridge University Press. ISBN 13: 9780521389150

DELUE, Rachel - ELKINS, James (2008). Landscape Theory. New York: Routledge. ISBN 9780415960540 .

DUNCAN, James S. - LEY, David (1993). Place/culture/representation. London-New York: Routledge, 1993. ISBN-13: 978-0415094511.

DVOŘÁČEK, Petr (2010). Skanzeny Ceské a Slovenské republiky [Open-air Museums in the Czech and Slovak Republic]. Praha: Academia. ISBN 978-80-200-1760-4.

FREDRIKSEN, Anders - MØRCH, Monica (2017). King Oscar II's collection of authentic medieval houses at Bygdøy, Oslo. In: Bulletin för trädgårdshistorisk forskning. vol. 30, 2017, pp. 13-15.

GAWEL, Artur (ed.) (2019). Open air museums in Poland. Białystok: Association of Polish OpenAir Museums. ISBN: 9788395486814.

GWARDZIŃSKA, Żaneta (2021). Agricultural Activity Run By Open-Air Museums in Poland. Muzealnictwo, vol. 62, no. 6, pp. 115-127.

HÁJEK, Pavel (2003). Česká krajina a baroko. Urbanismus českého baroka na př́kladu města Jičína a okolí [Czech Landscape and the Baroque: The Urban Planning of Czech Baroque Taking the Town of Jičín and Its Environs As an Example]. Praha: Malá Skála. ISBN 80902777-6-4.

HAVELKA, Miloš (2012). „Odkouzleni“" versus sekularizace?! [“Uncharming” vs Secularisation?! In: Sociológia, vol. 44, 2012, Issue 5, pp. 564-578.

HENDRYCH, Jan - LÍČENÍKOVÁ, Michaela (1998). Historická krajina Jičínska [Historical Landscape of the Jičín Region]. In: Zprávy památkové péče. Časopis státní památkové péče 3, 1998, pp. 76-83.

HERMOVÁ, Hana - POLKOVÁ, Miroslava -WATZKO, Karel (2007). Analýza vývoje území jako podklad pro současné plánování (na příkladu Mariánské zahrady na Jičínsku) [Analysis of Development of an Area as Underlying Document for the Present Urban Planning (Taking the Marianska zahrada Area in the Jičín Region As an Example)]. In: Historická geografie, No. 34, 2007, pp. 350-371.

CHODŹKO, Małgorzata (2017). Muzeum i skansen w kształceniu i wychowaniu : edukacja humanistyczna i cywilizacja techniczna w kontekście pedagogicznym = Museums and openair museums in education and upbringing: humanistic education and technical civilizations in the context of pedagogy. In: GRACA, Tadeusz - LAŻEWSKA, Dorota (eds), Edukacja bumanistyczna w kontekśsie technicyzacii w XXI wieku : w poszukiwaniu pedagogicznej równowagi, Józefów : Wydawnictwo Wyższej Szkoły Gospodarki Euroregionalnej im. Alcide De Gasperi, pp. 171-188. ISBN: 9788362753833

JACKOWSKI, Aleksander (1993). Czy wymyślilibyśmy dzisiaj muzea etnograficzne? In: Ślaskie Práce Etnograficzne, vol. 2, 1993, pp. 27-38.

JACKSON, John B. (1984). Discovering the Vernacular Landscape. New Haven. ISBN: 9780300035810.

KLEIN-WROŃSKA, Sonia - KROH, Magdalena - SADKOWSKI, Tadeusz (eds) (2016). Interaktywna edukacja w muzeach na wolnym powietrzu. Toruń: Stowarzyszenie Muzeów na Wolnym Powietrzu w Polsce. ISSN: 1509 - 2453 
KOTVASOVÁ, Helena (ed.) (2019). Múzéa v prírode: koncepcia, realita a vízie : z̧borník príspevkov z. prvého ročnika konferencie Únie múzé v prírode konanej 15. a 16. mája 2019 v Skanz̧ene Vychylovka. Čadca: Kysucké múzeum v Čadci. ISBN 978-80-89751-25-9

KUMINKOVÁ, Eva (ed.) (2019). Murea v př́rodě: jedinečná cesta murejnictví [Open-Air Museums: The Unique Way of Museum Science]. 1. vydání. Rožnov pod Radhoštěm: Národní muzeum $\mathrm{v}$ prírodě. ISBN 978-80-87210-72-7.

LANGER, Jiř́ (1976). Muzeum v prrírodě jako forma tezaurace památek lidového stavitelství [The Open-air Museum as a Form of Embalming Vernacular Architectural Heritage]. In: Národopisné aktuality. vol. 13, no. 3, 1976, pp. 179-184.

LANGER, Jiří. (1981) Národopisná muzea v přrodě. Teoretická a metodická východiska k realizaci [Ethnographical Museums in Nature. Theoretical and Methodological Bases for Their Realisation]. Rožnov pod Radhoštěm: Valašské muzeum v př́rodě.

LANGER, Jiří (2005). Atlas památek. Evropská muzea v prírodě [Atlas of Monuments. European Open-air Museums]. Praha: Baset. ISBN 80-7340-069-3.

MICHALIČKA, Václav (2009). Využití a smysl „experimentální“ a „aplikované“ etnografie [The Use and Importance of "Experimental" and "Applied" Ethnography]. In: Národopisný véstnike, vol. 26, no. 1(68), 2009, pp. 39-43.

NORBERG-SCHULZ, Christian (1979). Genius loci: Towards a Phenomenology of Architecture. New York: Rizzoli.

PAWLIKOWSKA-PIECHOTKA, Anna - ŁUKASIK, Natalia - OSTROWSKA-TRYZNO, Anna - SAWICKA, Karolina (2015). The Rural Open Air Museums: Visitors, Community and Place. In: European Countryside, vol. 7, no. 4, 2015, pp. 195-214.

PEDRAM, Behnam - EMAMI, Mohammad Amin - KHAKBAN, Mozhgan (2018). Role of the Open-Air Museum in the Conservation of the Rural Architectural Heritage. In: Conservation Science in Cultural Heritage, vol. 18, no. 12, 2018, pp. 101-120.

RENTZHOG, Sten. (2007) Open Air Museums: The History and Future of a Visionary Idea. Stockholm: Carlssons. ISBN: 978-9179482084.

RYCHNOVÁ, Lucie (2012). Stavebník František Josef Šlik [Frantz Joseph Schlik the Builder]. In: Východočeský sbornike historický, no. 21, 2012, pp. 163-196.

RYCHNOVÁ, Lucie (2014) Spisy o architekture, umění, zabradách a „dobrém żivotě" v knihovně Frantiskea Josefa Slike [Publications on Architecture, Art, Gardens and the "Good Life" in the Library of Frantz.Joseph Schlik], Marginalia Historica, vo. 5, no. 2, 2014, pp. 107-142.

RYCHNOVÁ, Lucie. (2020). František Josef Šlik a česká barokni krajina: život šlechtice na východočeském venkově. Praha: Scriptorium, 2020. ISBN 978-80-88013-99-0.

SCHAMA, Simon (1995). Landscape and Memory, New York: Knopf. ISBN 0-679-40255-1.

SCHLUCHTER, Wolfgang (2009). Die Entzauberung der Welt, Tübingen: Mohr Siebeck. ISBN 978-3-16-150139-5.

ŠEJN, Miloš (1999). Několik poznámek ke krajině [Several Remarks on Landscape]. In: Schlikové na Jičínsku, katalog $\mathrm{k}$ výstavě $\mathrm{v}$ Okresním muzeu a galerii v Jičíně, Jičín.

SEVAN, Olga (1984). Open Air Museums as Ways of Preserving and Transmitting the Spirit of Place. In: Proceedings of the 16th ICOMOS General Assembly and International Symposium: "Finding the Spirit of Place - Between the Tangible and the Intangible", Quebec, QC, Canada, 29 September-4 October 2008.

STACHOVÁ, Alena (2015). Vznik muzeí v př́rodě [The Founding of Open-Air Museums]. In: Prameny a studie, vol. 55, 2015, pp. 187-197. 
STEPANYAN, Knarik (2014). Open-Air Museums: Scenario Planning for the Future. In: Advanced Materials Research, vol. 1020, no. 10, pp. 711-715.

STRÁNÍKOVÁ, Jana - ŘíHOVÁ, Vladislava (2014). Kostel sv. Václava ve Veliši. Výstavba, vybavováni a okolnosti vaniku (1747-1752) [The Church of St Wenceslas in Veliš: Construction, Furnishing and Circumstances of Founding (1747-1752)]. Pardubice: Východočeské muzeum Pardubice. ISBN 978-80-87151-33-4.

ŠUBOVÁ, Dana (ed.) (2009). Medzinárodná konferencia prírodovedných pracovníkov múzei a pracovníkov múzei v prírode: zborník referátov : Liptovský Mikulás, 2009. Liptovský Mikuláš: Slovenské múzeum ochrany prírody a jaskyniarstva. ISBN 978-80-88924-71-5.

VOLMER, Lutz (ed.) (2018). Musealisierte Häuser: Bausubstan₹, Ideologien, Gründungspersönlichkeiten : ausgewählte Referate der 28. Jahrestagung des Arbeitskreises für ländliche Hausforschung in Nordwestdeutschland und der Interessengemeinschaft Bauernhaus e.V., 18. bis 20. März2016 in Bielefeld. Münster: Waxmann. ISBN: 978-3-8309-3915-3.

WEBER, Max (1998). Sociologie náboženství [Sociology of Religion]. Praha: Vyšehrad. ISBN 807021-240-3.

ZUSKINOVÁ, Iveta - KOLLÁR, Daniel - ONDREJKA, Kliment - AUGUSTINI, Peter et al. (2008). Open-air museums. Bratislava: Dajama. ISBN: 978-80-89226-59-7. 